\title{
GEOGRAPHICAL MELANISM IN THE LEPIDOPTERA OF SHETLAND
}

\author{
H. B. D. KETTLEWELL \\ Genetics Laboratory, Department of Zoology, University of Oxford
}

\section{FOREWORD}

Received 15.iv.6I

THE rapid spread of industrial melanism in the Lepidoptera which has taken place in the last 150 years has been a phenomenon unique in our knowledge and concept of biological changes. By experiment it has been shown that this spread is due in part to selective predation taking place in a changed environment (Kettlewell, 1956). This change has been brought about as an indirect effect of pollution fallout. The basic problem as to what part melanism has played in the past has, however, not been adequately answered. It is indeed surprising that melanic mutations seem to have arisen in so many species in so short a space of time, and even more so that the majority have had nearly complete dominance at inception. This suggests that in the evolution of melanism a preadapted genotype may have played a considerable part from time to time in the past history of those species manifesting it. Melanism may in fact confer advantages under a wide range of situations and certainly under circumstances very different from those in which the present-day industrial melanics are spreading. Some of these advantages may in part be due to the physical differences between black and white bodies.

It seemed possible, therefore, that field studies on the origin of non-industrial melanism might, at the same time, contribute to the larger subject of the origin and maintenance of polymorphism in general, about which there is at present so much speculation. A simple dimorphism involving the substitution of one colour form by another might be easier to study in the wild than those in more complicated situations.

It is a fact that although much has been written recently on the theory of polymorphisms (Williamson, r 958) and also on their genetical control, so far little experimental work has been undertaken in the field. Outstanding exceptions include the studies on the moth Panaxia dominula L. (Fisher and Ford, 1947), on the snail Cepea nemoralis L. (Cain and Sheppard, 1950), on the dimorphic females of Colias (Lep.) (Hovanitz, 1943), and on changes in the inversion frequencies in wild populations of Drosophila (Dobzhansky, 1959). Studies such as these, combined with laboratory investigations, have revealed basic mechanisms at work in the evolution of polymorphisms, such as disruptive selection to fulfil two optima (Mather, 1955; Thoday and Boam, 1959); the formation of the super-gene in mimicry and the simple 
switch mechanism controlling it (Clarke and Sheppard, i96o; Ford, 1953); the advantages of heterosis (Haldane, 1955, 1956) and the breakdown and build up of dominance (Kettlewell, 1958a).

It therefore seemed essential to attempt to analyse non-industrial melanism in a variety of situations and to try to determine the relative advantages and disadvantages of the melanic mutants under the prevailing conditions, and at the same time to study the underlying mechanisms responsible for maintaining these ancient polymorphisms.

\section{DISTRIBUTION OF NON-INDUSTRIAL MELANISM IN BRITAIN}

Out of approximately 6oo species of macro-Lepidoptera which occur in the southern half of Britain, probably fewer than ro maintain melanic polymorphisms in non-industrial areas. These are now confined to Wales, Devon, Cornwall and parts of other southern counties to the west of Surrey. The whole of eastern England must be considered as being affected by pollution fallout, the effects of which must overshadow long existing polymorphisms.

Non-industrial melanism is also found rather abruptly on the western coastlines, notably of Cornwall and to an even greater extent of western Ireland.

Melanism was also known to occur in other more specialised biotopes. It was established, for instance, that a number of species resident in relict Caledonian pine forests were polymorphic for melanism and that in Cleora repandata $\mathrm{Cl}$., the only one so far investigated, there was a one-gene difference between these two forms, the melanic form being dominant to the typical. Though probably of great antiquity, it is phenotypically similar to the Industrial Melanic mutant which is now found widespread throughout central industrial England. Furthermore, evidence was provided that each allele had both advantages and disadvantages in these ancient pine forests and that the result was a balanced polymorphism (Kettlewell, i957). Situations such as these no doubt today reflect local opportunities for the survival of melanic polymorphisms, but it is likely that in the past they were much more widespread. There exists, however, one major factor to be considered. Between latitude $50^{\circ}$ and latitude $60^{\circ}$ there is a correlation between the occurrence of melanism and the distance northwards. This is evident in the North American Continent where an examination of specimens in the American Museum of Natural History showed that the farther north samples were collected the higher both the frequency of melanic forms per species became and the number of species exhibiting melanism.

The same applies in Britain. The farther north one proceeds up to latitude $6 \mathrm{I}^{\circ}$ the more melanism is encountered, so that in Scotland it occurs in many species, both on the coast and inland. To the north of the Scottish mainland lie the Orkneys, Shetland and, farther 
north still, the Faeroes. In all these groups of islands melanic forms occur. It was decided, therefore, to investigate non-industrial melanism in one of these isolated areas.

\section{MELANISM IN THE SHETLAND ISLES}

It appeared to me that the Shetland Isles, where melanic forms were known to be common, would be the ideal place for a fuller investigation into non-industrial melanism. Here there could be no question of pollution fallout, and here the countryside has remained comparatively undisturbed by Man. During the last Ice Age (40,00o B.C. to I8,000 B.C.) it is likely that much of Shetland was not covered by ice, nor is it certain that it was covered during the last but one Ice Age (Strathmore) approximately Ioo,ooo years ago. If this is so, it is possible that some of the fauna may be very much older than previously believed.

We have undertaken two expeditions to the Shetland Isles, in I959 and I960. Of the 78 species of moths recorded from these islands, I 5 are migratory and are therefore unlikely to have acquired local forms. Migration may put a species at a disadvantage on the periphery of its range, in that an advantageous gene-complex, built up over previous years to adjust to local conditions, may be destroyed by an influx of fresh individuals from another environment (Haldane, I956). Of the 62 native species unaffected by migrant individuals 27 have produced local forms, and of these one-third are melanic. These may be classified into three groups:

I. Species in which Ioo per cent. of their population is melanic. They have discarded their normal alleles found elsewhere.

2. Species in which the two forms co-exist as a balanced polymorphism.

3. Species in which there is found an indefinite range of forms from black to pale; these presumably reflect either a multifactorial situation, or one in which variable heterozygotes occur.

The most obvious environmental change at these latitudes is the greatly diminished number of hours of darkness during summer and, what is probably more important, the long periods of twilight. These coincide with the warmest months in the year, when the majority of moth species appear as adults. This necessitates their taking flight in daylight. Under these conditions light coloured insects, which farther south have the protection of darkness, are more conspicuous than dark ones, so that extensive predation could take place if predators were available. We are able to provide evidence that in Shetland bird predators are extremely common, particularly in the north, and furthermore that they feed on moths both on the wing and on the ground. Farther north, however (above latitude $6 \mathrm{I}^{\circ}$ ), melanic polymorphisms are less frequent. In the Faeroes, of the 23 indigenous 
species (Wolff, 1929) only 4 (23 per cent.) show melanism and in Iceland 2 (10 per cent.) out of 21 . This may reflect a relaxation of bird predation farther north, though this is unlikely to be the only reason.

Examples of melanic Lepidoptera found in Shetland are shown on plate I. Figs. I and 2 depict the English and Shetland forms of Diarsia festiva, Schiff. respectively, the latter being referred to as ssp. thulei, Staud. This race is distinct in appearance from $f$. typica of the British mainland, being darker and smaller, and falls into group I of the classification. We have bred the larvæ from ova, and we find that they bear little resemblance to those of festiva f. typica. One of our team, C. J. Cadbury, has succeeded in crossing the two races. The majority of larvæ and the single moth bred from them were intermediate in appearance between the parental races. It is likely that several genes are involved in the differences: ssp. thulei seems, in fact, to be well on the way to speciation. It is a good example of group I of our classification. Other species which are in a similar position are Eupithecia venosata, Fabr. and Hadena conspersa, Esp. (figs. 3-4). Both these feed exclusively in the Shetlands on Silene maritima, the Sea Campion, and are therefore limited to the shoreline. Though in Shetland considerable variability occurs in both these species, examples are never as light as the $f$. typica found elsewhere.

Species showing a clear-cut polymorphism (group 2) with distinct phenotypes suggesting disruptive selection are uncommon. However, one of the most successful of species in the Shetlands, Amathes glareosa, (Esper, 1788), which is to be discussed in considerable detail in the following two papers, falls into this category (plate II, fig. I). It will be noted that $f$. typica has little resemblance to the black $f$. edda (Staudinger, $189 \mathrm{I}$ ). Lygris populata L. should be relegated to the same group with its black $f$. masanaria, Freyer, but in this species the melanic is variable (plate I, figs. 5-6). Amathes xanthographa, Fabr. (plate I, figs. 7 and 8) should also be included in group 2 .

Group 3, in which an indefinite range from pale to dark forms occurs, contains the majority of species. Amongst these are the following: Entephria cesiata Schiff. (plate I, figs. 9 and 10), Xanthorhoë fluctuata L. (plate I, figs. I I and I2) and Hepialus humuli L. (plate I, figs. 13 and 14). The Shetland melanic form of E. cosiata, ab. atrata Lange, is phenotypically identical to the industrial melanic form found near Paisley in Scotland, and specimens from both localities are referred to by this name.

The genetic control of melanism found in a similar situation to that of some species in Shetland has been analysed by Ford (1953). $F$. curtisii of Triphena comes L. which occurs in North Scotland, is controlled by a major gene which has incomplete dominance. Ford demonstrated that the degree of expression of melanism was materially affected by the constitution of the gene-complex. He showed that when curtisii from the island of Barra was out-crossed into a genecomplex from Orkney (with which it could have had no recent contact) 
the heterozygote curtisii were much more variable. Whereas the phenotypes had segregated in his initial wild stock, there was now a complete gradation from black to light. This demonstrated that the melanism of $f$. curtisii depends on one major gene which, however, expresses itself differently according to the modifying genes present.

This grouping of non-industrial melanism under three headings must therefore be considered arbitrary. Though others might place certain species in a different category, it is a convenient method of classification as a first step to understanding the origin of melanic polymorphism in Shetland. The classification into three groups reflects phenotypic expression which may bear no relationship to their genetic control.

\section{PREVIOUS SHETLAND DATA}

Not until the end of the last century was it realised that the Shetland insect fauna was very different from that found on the British mainland. At that time the interest was, as it still is to a large extent, in obtaining specimens for collections. Shetland offered few comforts then for collectors and was largely inaccessible. It is not surprising, therefore, that the few Lepidopterists who visited these islands were professional collectors, sent there to bring back as many aberrant specimens as possible, and paid by wealthy collectors who were not prepared to undergo the hardships themselves. A more important consideration is that the emphasis was therefore on extreme examples and that, as is the rule in all collections, the insects which were kept bore no relationship to their frequency in the populations from which they had been extracted. All normal specimens, similar to those found on the British mainland, were discarded. Violent frequency changes appeared in their yearly samples, and these were interpreted as reflecting the direct effect of seasonal differences on the insects themselves.

One of the first collectors to work in Shetland was McArthur, who visited the Mainland in 1880 and 1881 and subsequently Unst in 1883 (Weir, 1880, 188 I and 1884). He recorded a large number of melanic forms. The current explanation at this time was that melanism was the direct effect of humidity, and so it is not surprising to find that South (1893), who had never been to Shetland, decided that McArthur's melanic forms came from "boggy meadows", whereas the more normal individuals were collected on drier cliffs and hillsides. More specifically he refers to $H$. humuli as behaving in this way. Similarly he appears to have thought that the dark form of $A$. glareosa, $f$. edda, was confined to "low-lying wet moors near Baltasound". Other collectors about this same period were L. A. E. Sabine and Salvage, many of whose specimens can be found in the British Collection of Lepidoptera of the British Museum (Natural History) at Tring, but they published no records, presumably wishing to retain a financial monopoly. 
Shetland has been visited on many occasions by collectors during the present century (Hare, I957; Harper, 1958) but with the same object of procuring specimens for their own private collections only. On no occasion have frequencies of the forms been recorded. The reasons for melanism in the Shetland Lepidoptera have remained obscure.

\section{CHOICE OF MATERIAL}

In attempting to investigate and analyse the advantages and disadvantages of melanic forms in the wild, under the difficulties imposed by climate and lack of facilities, and without guidance from previous work, it is necessary to choose a subject which offers as few complications as possible. Easy recognition of the melanic form is therefore essential and also the choice of a species which is common, widespread and which could easily be collected. Mark-releaserecapture experiments were envisaged in which the two contrasting forms would be released at the extremes of their frequencies. Furthermore, a clear-cut dimorphic species would be desirable, and one which would conform with the majority of situations found in industrial melanism.

For these reasons I decided to undertake a full investigation into the species $A$. glareosa Esp. and its dark form edda, Staud.

\section{THE NATURAL HISTORY OF AMATHES GLAREOSA ESP.}

(i) Description of Morphs.

With the exception of Shetland and the Orkneys, only the typical form of this species is found throughout its range (plate II, fig. I). In this the ground colour is either light grey or light grey tinged with pink: pink forms are commoner in the southwest of England. Occasional specimens with a dark ground colour have in the past been recorded from parts of Yorkshire and also from Perthshire (Barrett, I897). In Shetland $f$. typica is more usually of a slate-grey colour. On each forewing there are two conspicuous black wedge-shaped marks with their broad bases lying towards the costa. This pattern is without doubt disruptive. The efficiency of its patterning must therefore vary according to the depth of vegetation and the angle and brilliance of the sun. In common with most Noctuid moths the forewings alone are visible when at rest, and these marks serve to break down the insects' outline in the shadows cast by overlying foliage (plate II, fig. 2).

The melanic form edda was first discovered by McArthur in I883 (Weir, I884). It is found only in Shetland, including Fair Isle, and the Orkneys: A. glareosa does not occur in the Faeroes. F. edda bears little resemblance to $f$. typica. It is of a dark brown-black colour with light orbicular and reniform outlines on the forewings. The thorax is, however, greyish in many specimens. It is important to note that 
the hindwings, which are only exposed in flight, are of a light colour. A further observation is that not only is the dorsal surface of the abdomen black, but also the ventral. This is an unusual occurrence in melanic Lepidoptera that have light-coloured hindwings, and must have a survival value. The significance of this will be discussed later. In its normal resting position on a peaty background $f$. edda is most difficult to see (plate II, fig. 3). This form therefore reflects the substitution of a disruptive pattern by a highly efficient cryptic one when resting on peat.

\section{(ii) Habits of Imago}

The species begins to emerge in the first week of August and in Shetland has a peak period in about the third week. By the end of the first week in September it is becoming scarce. On the British mainland, however, the period of emergence is longer, and I have taken a specimen in Cornwall as late as early October. The moth spends the day motionless on the surface of the ground beneath heather, but on wet days I have observed that it runs under small stones and then takes up a position so that only its head and thorax are visible. It flies at dusk, and the maximum flight period is probably half an hour later. It is attracted freely to light, particularly ultra-violet. It visits flowers regularly, especially heather, but in the south I have also taken it on ivy blossom. This species comes but reluctantly to artificial baits such as "sugaring mixtures". Mating occurs before midnight, almost certainly on the day of emergence, and pairs can occasionally be found in copula hanging from wire fences. Ovipositing most likely does not commence before the following night. In order to contribute to the next generation it is therefore necessary for the females to survive one period in daylight. This is a most important consideration. Most cryptic species hatch under cover of darkness, thereby avoiding immediate exposure on a possibly incorrect background. It has been pointed out that a species which hatches at dusk, pairs rapidly and succeeds in laying all its eggs on the first night would escape the consequence of visual predation, and that therefore colour and pattern would be of little consequence to survival (Kettlewell, 1958b). This is not the situation in $A$. glareosa, which we have shown may live up to two weeks in the wild, during the whole of which period ovipositing can be undertaken. We have observed that visual predation by birds takes place extensively. It is likely, therefore, that the two forms would have a different mortality rate due to selective predation and that this would vary according to the conditions under which they have to pass the day. It is in fact likely that this colour difference may play a major part in maintaining this polymorphism.

\section{(iii) Life history}

There is a one-year life-cycle, but it is possible that occasionally, in common with other northern species, a second winter may be passed in the pupal state. The moth lays its eggs singly, probably 
on heather in the wild, but in captivity on heather, muslin or cardboard. They are spherical and ribbed and of a pale yellow colour. After a few days fertile ova can be recognised by flecks of red appearing around the upper pole. After two or three weeks the eggs darken and by the beginning of October all ova are blackish-grey. The following eight weeks is certainly a most vulnerable period in the life history of the species; in 1959, Ioo per cent. of our stock died at this stage, and on dissection the eggs were found to contain fully formed larvæ. In 196o, by keeping ova cool and in a damp atmosphere, we succeeded in hatching a large proportion of them, but the period over which they hatched varied from 30 to 80 days, and within one brood $(\mathrm{g} / 24 / 60)$ from 47 to 80 days. It seems in fact as though the larva goes into hibernation for a period within its eggshell. This is a well known phenomenon in certain species such as Lasiocampa trifolii L. Furthermore, in A. glareosa, no matter under what conditions the young larvæ were kept, a large proportion died in the first twenty-four hours after hatching. Although our broods were distributed to many of the best breeders in Britain, all had the same results. It is likely that a heavy mortality takes place in nature at this same period in the life history of the species. Those larvæ which survive the first fortyeight hours attain full growth with a comparatively low mortality rate. In warmth in the laboratory we accomplished this in under two months. In nature it is probable that the small larvæ feed slowly on warm nights throughout the winter. This much we know for certain; that full-grown larvæ have been found but rarely in the spring, and then only at night. They were feeding on plants such as hyacinth (Barrett, 1897). They pupate in April or May, and they do this in cocoons below the surface of the ground. Both larva and pupa are therefore largely protected from visual predation.

\section{(iv) Genetics of A. glareosa f. typica and f. edda}

$F$. edda has never previously been bred in the laboratory. $A$. glareosa is a very difficult species to rear in captivity; furthermore the larva has only rarely been found in the wild. We are at present engaged in breeding the offspring of 46 wild females. Table I gives a list of the wild caught female phenotypes along with their local gene frequencies and the number of imagines which have emerged up to date. From these data, particularly those of broods g/22/6o and $\mathrm{g} / \mathrm{I} 4 / 6 \mathrm{o}$, it appears that $f$. edda is dominant to $f$. typica. F. edda varies from a light brown to black, but there is no obvious segregation within the $e d d a$ of our broods. The females are usually darker than the males and this applies particularly to the hindwings. In the north of Shetland, where the heterozygotes must form approximately i2 per cent. of the population, the very black form is common and pale edda less so. In the south, however, where edda forms only 2 per cent. of the population, the black form is rare and nearly all the edda are less 
extreme. We have further proof that these two forms are controlled genetically in that two of our party took a halved mosaic in south Shetland in which one side was largely $f$. edd $a$ and the other $f$. typica.

TABLE $\mathbf{I}$

Breeding results: Amathes glareosa, 1960-6 I

\begin{tabular}{|c|c|c|c|c|c|}
\hline Brood no. & $\begin{array}{l}\text { Phenotype of } \\
\text { parent }\end{array}$ & Locality & $\begin{array}{c}\text { Typica } \\
\text { local gene- } \\
\text { frequency } \\
\%\end{array}$ & Typica & Edda \\
\hline $\mathrm{g} / 37 / 60$ & typica & Unst & $16 \cdot 4$ & 0 & \\
\hline $\mathrm{g} / 4 \mathrm{o} / 6 \mathrm{oo}$ & edda (light) & & $16 \cdot 4$ & o & 3 (2 dark) \\
\hline $\mathrm{g} / 29 / 60$ & typica & Mainland Reawick & $63 \cdot 7$ & $\mathrm{o}$ & \\
\hline $\mathrm{g} / 2 / 60$ & & Aith & 66.3 & 5 & 7 (light) \\
\hline $\mathrm{g} / 3 \mathrm{I} / 60$ & edda & $\begin{array}{l}\text { Skellister } \\
\quad \text { (S. Nesting) }\end{array}$ & $6 \mathrm{I} \cdot \breve{6}$ & 3 & \\
\hline$g / 13 / 60$ & $"$ & $\begin{array}{l}\text { N. border of } \\
\text { Tingwall Valley }\end{array}$ & $86 \cdot 9$ & I & I \\
\hline$g / 19 / 60$ & ", & " " & $86 \cdot 9$ & 0 & 6 \\
\hline $\mathrm{g} / 20 / 60$ & ", & ", & $86 \cdot 9$ & I & 2 \\
\hline $\mathrm{g} / 21 / 60$ & , & ," & 86.9 & I & $\mathrm{o}$ \\
\hline $\mathrm{g} / 22 / 60$ & ," & & $86 \cdot 9$ & $\mathrm{o}$ & I2 (3 dark) \\
\hline $\mathrm{g} / \mathrm{I} / \mathrm{6} / 6 \mathrm{o}$ & ", & $\begin{array}{l}\text { S. border of } \\
\text { Tingwall Valley }\end{array}$ & $88 \cdot 7$ & 3 & I 6 (2 dark) \\
\hline$g / 15 / 60$ & " & , , , & 88.7 & 2 & o \\
\hline$g / 16 / 60$ & ," & n ," & $88 \cdot 7$ & I & I \\
\hline $\mathrm{g} / 8 / 60$ & $"$ & Boddam & $99^{\circ} \mathrm{o}$ & 0 & 2 \\
\hline $\mathrm{g} / 9 / 60$ & $"$ & ," & $99^{\circ} \mathrm{o}$ & $\mathrm{o}$ & I \\
\hline$g /$ I I $/ 60$ & ", & $"$ & $99^{\circ} \mathrm{O}$ & I & $\mathrm{o}$ \\
\hline & & & \multicolumn{2}{|c|}{ Total bred $=\mathrm{I} 8$} & 50 \\
\hline
\end{tabular}

In the following two papers, the distribution of the two forms of A. glareosa, and also their differential survival and habit differences, are discussed.

\section{SUMMARY}

I. In previous papers $I$ have produced evidence on the factors responsible for the rapid spread of industrial melanism in the Lepidoptera. I suggested that melanism might in the past have conferred advantages under conditions very different from those found today.

2. Evidence was provided that non-industrial melanism still occurs in the world today in widely different environments and that here we might discover the previous benefits conferred by melanism.

3. We have established that there is a correlation between the amount of melanism and the distance northwards between latitudes $50^{\circ}$ and $60^{\circ}$. forms.

4. In the Shetland Isles one-third of the moth species have melanic 
5. It was decided to investigate one species and attempt to analyse the advantages and disadvantages of its two morphs in a state of apparent long-standing balanced polymorphism.

6. The species selected was Amathes glareosa Esp. and its melanic form edda. The genetical control of the two forms, the life history and habits are discussed in this paper.

\section{REFERENCES}

BARRETt, C. G. I 897. The lepidoptera of the British Isles. IV., 30-34.

CAIN, A. J., AND ShEPPARD, P. M. 1950. Selection in the polymorphic land snail Cepra nemoralis. Heredity, 4, 275-294.

Clarke, C. A., AND ShepPaRd, P. м. I96o. Super-genes and mimicry. Heredity, $14,175-185$.

DoBZHANSKY, TH. 1959. Changes in Invasion frequencies in Californian populations of Drosophila pseudoobscura since 1941. Proc. XVth Int. Cong. Zoo., I69-I 7o.

ESPER, E. J. C. I 788 . Der europäischen Schmetterlinge. Vierten theils, zweiter band. eulenphalenen. Europ. Schm., 4, 387 .

FISHER, R. A., AND FORD, E. B. 1947. The spread of a gene in natural conditions in a colony of the moth Panaxia dominula L. Heredity, I, I43-I 74 .

FORD, E. B. I953. The genetics of polymorphism in the lepidoptera. Advances in Genetics, 5, 43-87.

HALDANE, J. B. S. I955. On the biochemistry of heterosis and the stabilization of polymorphism. Proc. roy. Soc., B., I44, 2 I 7-220.

HALDANE, J. B. s. 1956. The theory of selection for melanism in Lepidoptera. Proc. roy. Soc., B., I45, 303-308.

HARE, E. J. 1957. Unst Revisited. Ent. Rec., 69, 8o-83.

HARPER, B. W. I958. Northern lights-a visit to Unst. Ent. Rec., 7o, 286-288.

Hovanitz, w. I943. The distribution of gene-frequencies in wild populations of Colias. Genetics, 29, I-30.

KetTLEWELL, H. B. D. I956. Further selection experiments on industrial melanism in the Lepidoptera. Heredity, Io, 287-30 I.

KETTLEWELL, H. B. D. I957. Industrial melanism in moths and its contribution to our knowledge of evolution. Proc. Roy. Instn., 36, I-I 3.

KETTLEWELL, H. B. D. I 958 . A survey of the frequencies of Biston betularia L. (Lep.) and its melanic forms in Great Britain. Heredity, I2, $5 \mathrm{I}-72$.

KETTLEWELL, H. B. D. I $958 b$. The importance of the microenvironment to evolutionary trends in the Lepidoptera. Ent., 9I, 214-224.

mather, K. 1955. Polymorphism as an outcome of disruptive selection. Evolution, $I X, 52-6 \mathrm{I}$.

south, R. I 893. Lepidoptera of the Shetland Islands. Ent., 26, 98-102.

STAUDINGER, o. I89i. Neue arten und varietäten von lepidopteren des paläarktischen faunengebiets. Iris., $4,266$.

THODAY, J. M., AND BOAM, т. в. I959. Effects of disruptive selection II. Polymorphism and divergence without isolation. Heredity, 13, 205-2 18.

WEIR, J. J. 1880. The Macro-Lepidoptera of the Shetland Isles. Ent., r3, 249-29r. WEIR, J. J. I88 I. Further Macro-Lepidoptera of the Shetland Isles. Ent., 14, 278281 .

WEIR, J. J. I884. The Macro-Lepidoptera of Unst. Ent., I7, I-4.

williamson, м. н. 1958. Selection, controlling factors and polymorphism. Am. Nat., 92, (876), 329-335.

WOLFF, N. L. 1929. Lepidoptera, in Zoology of the Faroes, 39, I-38. Copenhagen, I 929. 


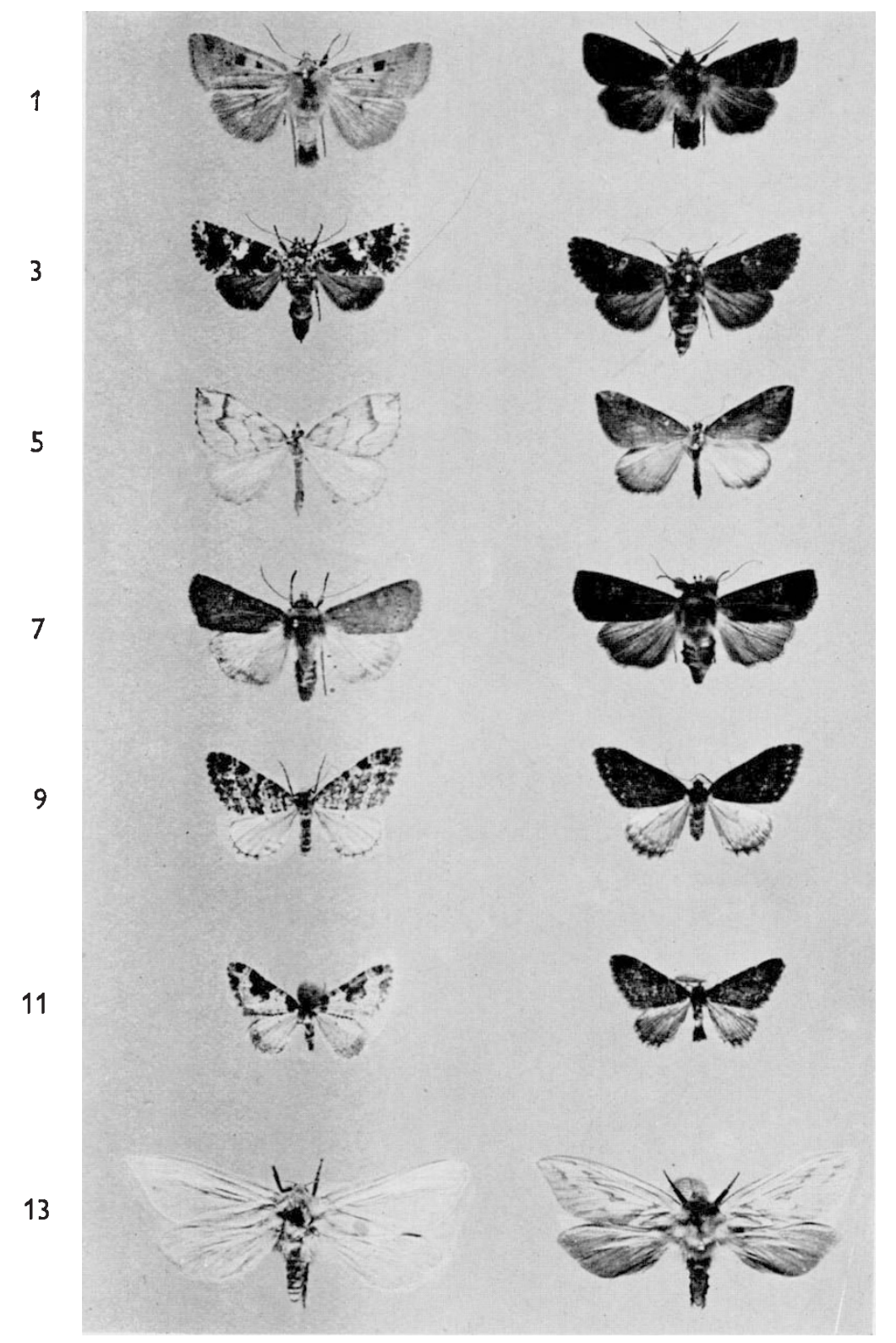

Plate I

Shetland Lepidoptera with their melanic forms. $\times \frac{3}{4}$.

FIGs. 1 and 2.-Diarsia festiva. Schiff and ssp. thulei, Staud.

FIGs. 3 and 4.-Hadena conspersa, Esp. and melanic Shetland form.

FIGs. 5 and 6.-Lygris populata, L. and Shetland form masanaria.

FIGS. 7 and 8.-Amathes xanthographa Fabr. and Shetland melanic form.

FIGs. 9 and 10.-Entephria cesiata, Schiff, and $f$. atrata, Lange.

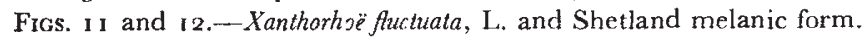

Figs. 13 and 14.-Hepialus humuli, L. and Shetland f. Shetlandica.

(Photo 7. Haywood, Oxford University). 

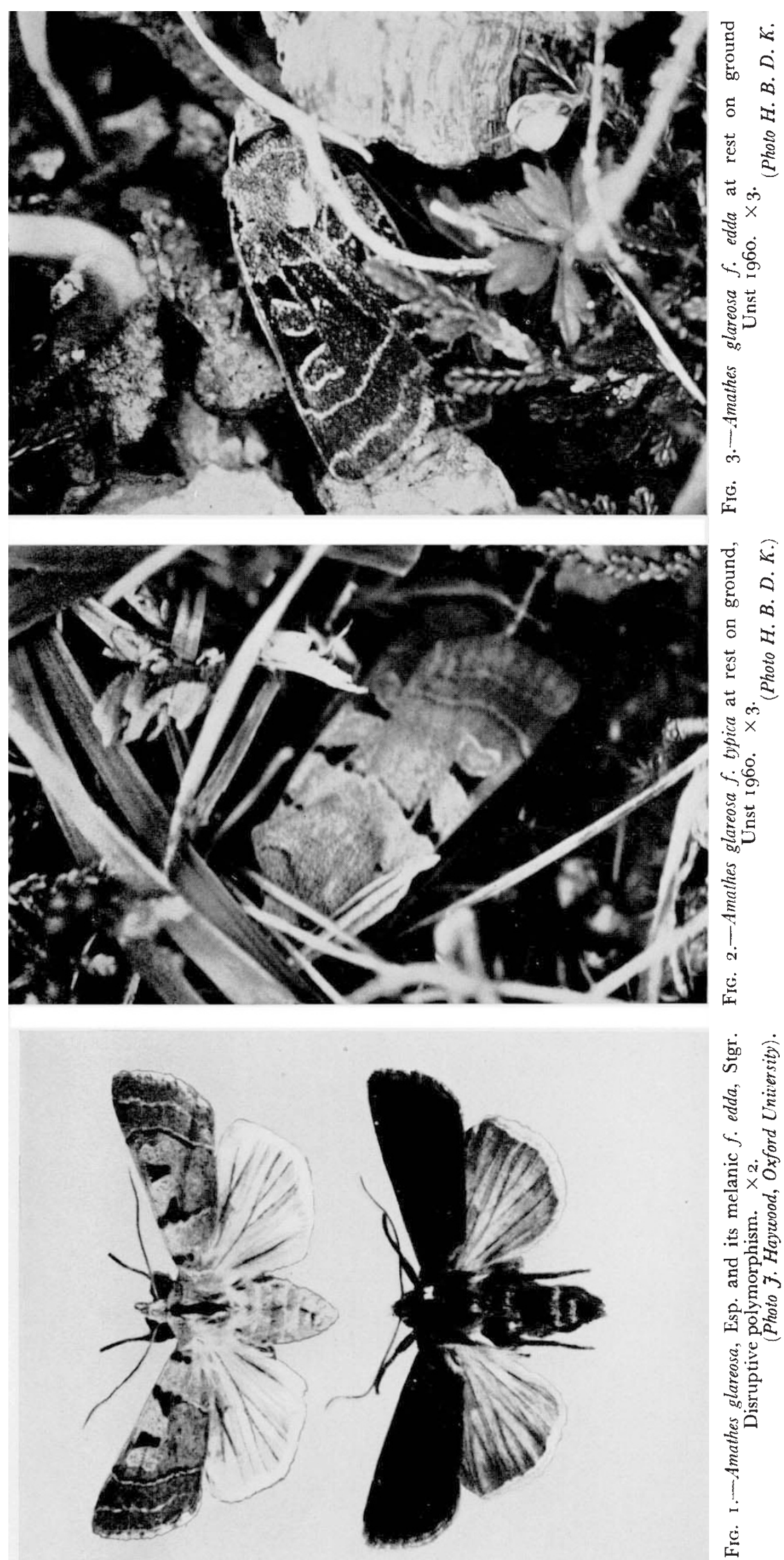